\title{
On the social dynamics of moisture recycling
}

\author{
Patrick W. Keys ${ }^{1,2}$ and Lan Wang-Erlandsson ${ }^{2,3}$ \\ ${ }^{1}$ School of Global Environmental Sustainability, Colorado State University, Fort Collins, USA \\ ${ }^{2}$ Stockholm Resilience Centre, Stockholm University, Stockholm, Sweden \\ ${ }^{3}$ Research Institute for Humanity and Nature, Kyoto, Japan
}

Correspondence: Patrick W. Keys (patrick.keys@colostate.edu)

Received: 4 December 2017 - Discussion started: 6 December 2017

Revised: 15 May 2018 - Accepted: 17 May 2018 - Published: 14 June 2018

\begin{abstract}
The biophysical phenomenon of terrestrial moisture recycling connects distant regions via the atmospheric branch of the water cycle. This process, whereby the land surface mediates evaporation to the atmosphere and the precipitation that falls downwind, is increasingly well-understood. However, recent studies highlight a need to consider an important and often missing dimension - the social. Here, we explore the social dynamics of three case study countries with strong terrestrial moisture recycling: Mongolia, Niger, and Bolivia. We first use the WAM-2layers moisture tracking scheme and ERA-Interim climate reanalysis, to calculate the evaporation sources for each country's precipitation, a.k.a. the precipitationshed. Second, we examine the social aspects of source and sink regions, using economic, food security, and land-use data. Third, we perform a literature review of relevant economic links, land-use policies, and land-use change for each country and its evaporation sources. The moisture-recycling analysis reveals that Mongolia, Niger, and Bolivia recycle 13, 9, and $18 \%$ of their own moisture, respectively. Our analysis of social aspects suggests considerable heterogeneity in the social characteristics within each country relative to the societies in its corresponding evaporation sources. We synthesize our case studies and develop a set of three system archetypes that capture the core features of the moisturerecycling social-ecological systems (MRSESs): isolated, regional, and tele-coupled systems. Our key results are as follows: (a) geophysical tele-connections of atmospheric moisture are complemented by social tele-couplings forming feedback loops, and consequently, complex adaptive systems; (b) the heterogeneity of the social dynamics among our case studies renders broad generalization difficult and highlights the need for nuanced individual analysis; and, (c) there does not appear to be a single desirable or undesirable MRSES, with each archetype associated with benefits and disadvantages. This exploration of the social dimensions of moisture recycling is part of an extension of the emerging discipline of socio-hydrology and a suggestion for further exploration of new disciplines such as socio-meteorology or socio-climatology, within which the Earth system is considered as a coevolutionary social-ecological system.
\end{abstract}

\section{Introduction}

Humanity is unequivocally leaving its mark on Earth, in terms of changes to the land surface (Ellis and Ramankutty, 2008), biostratigraphic layers (Zalasiewicz et al., 2015), and global hydrologic cycles (Zhou et al., 2016). Against this backdrop of heedless, anthropogenically driven Earth system change, there have emerged new insights into the interactions between land-use change and the atmospheric branch of the water cycle. That land-use change can and does influ- ence the atmospheric water cycle is well-supported (e.g., Lo and Famiglietti, 2013; Wei et al., 2013; Halder et al., 2016; Vrese et al., 2016). Impacts can include modifications of the energy budget (e.g., Swann et al., 2015), impacts on local or regional circulation (e.g., Tuinenburg et al., 2014), and impacts on the atmospheric water cycle (e.g., Spracklen and Garcia-Carreras, 2015; Badger and Dirmeyer, 2015).

The general process of water evaporating from the surface of the Earth, traveling through the atmosphere as water vapor, and eventually falling out as precipitation downwind 
is known as moisture recycling (Lettau et al., 1979; Koster et al., 1986). The component of this process that takes place over land is often distinguished as terrestrial moisture recycling (as opposed to oceanic moisture recycling) (van der Ent et al., 2010). However, in the context of this paper and for the sake of brevity, we will use the phrase moisture recycling to refer specifically to the terrestrial component. Considering the recent debate regarding human impacts on large-scale hydrology (Rockström et al., 2012; Heistermann, 2017), there is a need to clarify and highlight the importance of anthropogenic modification of terrestrial moisture recycling. Moreover, it is incumbent on the scientific community to begin understanding how the constituent components of the Earth system interact with the social.

Any research on moisture recycling that is either driven by anthropogenic land-use change or is seeking to understand how changing moisture recycling impacts land use has a social component. The range of social topics that have been explored in the context of moisture recycling include natural hazards and flooding (Dirmeyer and Brubaker, 1999; Dominguez et al., 2006), irrigation impacts on moisture recycling (Lo and Famiglietti, 2013; Tuinenburg et al., 2014), rainfed crop production (Bagley et al., 2012; Keys et al., 2012), ecosystem services (Ellison et al., 2012; Keys et al., 2016), urban water vulnerability (Keys et al., 2018), and even the import and export of moisture among nations (Dirmeyer et al., 2009; Keys et al., 2017). Land-use change impacts on rainfall via moisture recycling have been suggested to be potentially linked to the Sahel drought during the 1970s, and this moisture-recycling mechanism was suggested to be an integral part of the socio-hydrology discipline (Sivapalan et al., 2012). These preliminary examinations of moisture recycling in the context of social issues have been revealing, but the social domain has often been investigated outside the biophysical system feedback boundaries, either as an initiator of hydrological change (e.g., land-use change) or as a receiver of hydrological change (e.g., decreasing crop yields) but almost never as dynamic modifier of hydrological change.

Social ecology, however, departs from the view that human and environmental systems are separate and that socialecological systems (SESs) are tightly coupled complex adaptive systems. In its simplest form, the classic socialecological systems diagram (Holling, 2001; Folke et al., 2004; Folke, 2006) includes an ecological node, a social node, and arrows connecting the two nodes to one another as well as feeding back on themselves. Recognizing that systems exist within hierarchies, the concept of panarchy was developed for understanding the cyclic dynamics of combined human-nature systems across scales (Gunderson and Holling, 2002). For the purpose of analyzing the likelihood of self-organization in SESs, Ostrom (2009) proposed a general multilevel, nested framework comprised of resource system, resource unit, governance system, and users, which are all embedded within ecological as well as social-economical- political settings. In terms of water management and governance, this type of SES thinking has been primarily applied to rivers and lakes (Cosens and Williams, 2012; Gunderson et al., 2017) but not to atmospheric moisture flows.

\section{Research questions and rationale}

Here, we take inspiration from the SES type of thinking to address the social dynamics of moisture recycling by posing the following questions:

1. How are moisture-recycling patterns interlinked with social dynamics?

2. Are there dynamic social connections that link precipitation sinks and sources?

3. What are the system architectures that create feedbacks among geophysical, ecological, and social drivers?

We want to be clear that our analysis includes both objective analysis of moisture recycling and social data as well as subjective assessment of ongoing policy and management activities related to land-use change. This blending of quantitative and qualitative, as well as objective and subjective, is at the heart of our approach to understanding the social dynamics of moisture recycling.

This work will be useful for three key reasons. First, the conceptual approach will provide Earth system scientists who study the atmospheric water cycle with the basics of how social systems (that are the sinks of upwind moisture recycling) are connected in many different ways back to the moisture sources. Second, this conceptual insight provides an entry point for more accurate modeling of the feedbacks that could affect moisture-recycling patterns (rather than only considering, e.g., geophysical phenomena). Third, this paper provides insights for resource managers, particularly land and water managers, who are searching for new leverage points within their dynamic social-ecological systems. Understanding where key feedbacks, bottlenecks, and potential cascades are located within a system can provide managers with better information about the consequences of direct or indirect intervention within their systems.

We argue that exploring the social dynamics of moisture recycling improves our understanding of Earth system dynamics by providing general insight into how humanity modifies the Earth system but also into the heterogeneity of moisture-recycling social-ecological systems.

\section{Methods and data}

\subsection{Conceptual development}

We propose to develop a framework for moisture-recycling SESs, starting with the classical social-ecological systems concepts (Holling, 2001; Folke et al., 2004; Folke, 2006) (Fig. 1a). A key feature of SESs is the connections among 
different system components, creating loops. These system loops allow for feedbacks within the system, leading to complex, emergent behavior. Likewise, the systems can adapt to changing conditions, making them complex adaptive systems. In parallel, we use the simplest representation of a moisture-recycling system, which comprises the source of evaporation and the sink of precipitation (Fig. 1b). Typically, the direction flows from the source to the sink, with some amount of internal recycling within the source as well as the sink. The absence of a connection from the sink back to the source is because the moisture-recycling relationship is based on purely biogeophysical connections, with water evaporating from the source, traveling along prevailing wind currents as water vapor, and condensing and falling as precipitation elsewhere. However, it is possible to place an SES within both the source and sinks (Fig. 1c). This nesting of SESs within the moisture-recycling system suggests the emergence of a social connection back from the evaporation source to precipitation sink (Fig. 1c, red) and represents the fundamental basis for our current research. Furthermore, this concept of a moisture-recycling social-ecological system (MRSES) will be used to develop archetypes that can guide model development and practitioner prioritization. To construct the archetypes, we explore three case studies to identify how the geophysical and social connections interact to create feedbacks and how these feedbacks lead to broader system dynamics. A table of key terms is provided for reference, especially given the interdisciplinary nature of this research (Table 1 ).

\subsection{Case study selection}

To find regions that are both relevant to terrestrial moisturerecycling dynamics, as well as (potentially) relevant to social dynamics, we use regions selected from the work in Keys et al. (2016), who identified global regions that are particularly reliant on current vegetation for rainfall from moisture recycling (Keys et al., 2016; see Fig. 2b in the present paper). The regions that receive the most (relative) precipitation from upwind vegetation-regulated evaporation are east and central Asia, parts of the Sahel, southwestern Africa, the southern Amazon and the La Plata River basin in South America, and much of Canada. We also aimed to select regions that were "socially relevant" which, in this work, we define as having potential social-ecological inequalities (e.g., differences in child malnutrition) among the downwind beneficiaries of moisture recycling and the upwind providers of moisture recycling. Furthermore, since this research is about social dynamics, we select countries as our unit of analysis rather than hydrological units (e.g., basins) or biophysical units (e.g., specific landscapes).

Based on these criteria, the selected case studies are Mongolia, Niger, and Bolivia. These three sink regions are distributed across three continents, providing separate moisturerecycling dynamics and distinct social systems while having (a) Social-ecological systems (SESs)

(b) Moisture recycling
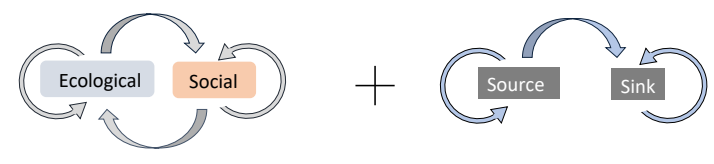

(c) Moisture-recycling social-ecological system (MRSES)

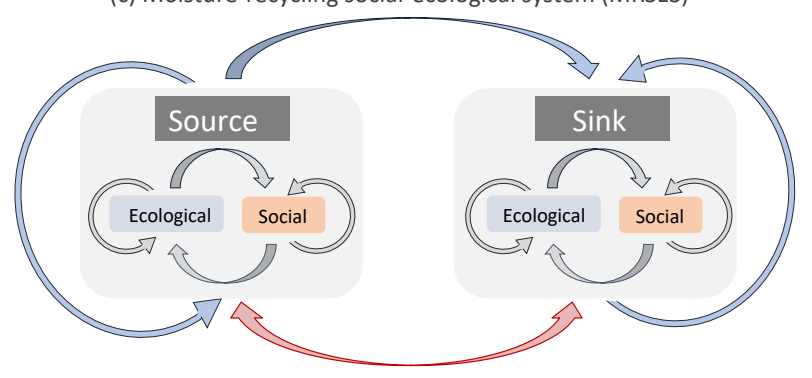

Figure 1. Conceptual construction of moisture-recycling social ecological system (MRSES) archetypes. A hypothetical, idealized social-ecological system (a) is nested within the idealized moisturerecycling system (b), creating a linked moisture-recycling socialecological system (c). The red arrow at the bottom of (c) emphasizes the fact that the social aspects of a MRSES are what link the precipitation sink back to its evaporation sources. The arrow points in both directions, since social links are not restricted by biophysical constraints.

a comparable spatial footprint (with subsequently comparable moisture-recycling source and sink footprints).

For each of these case studies, we identify (a) the discrete sources of evaporation falling as precipitation within the case study, i.e., the precipitationshed (Keys et al., 2012); (b) the dominant land-use types that are present in the sink and the precipitationshed; (c) a quantitative comparison of social dynamics in sources and sinks; and, (d) a qualitative literature review of the types of social dynamics present within the precipitationshed.

\subsection{Tracking the sources of moisture}

We use an "offline Eulerian" moisture tracking scheme called the Water Accounting Model-2layers, hereafter, WAM2layers (for original model configuration, van der Ent et al., 2010; for two-level update van der Ent et al., 2013). For a single grid cell and corresponding column of air, the model works as follows: first, the amount of moisture entering the column as evaporation is tracked; second, the evaporated water mixes with the moisture in the lower and upper levels of the column; third, moisture blows into and out of the column from adjacent columns; and, fourth, a certain amount of precipitation exits the lower level of the column. This tracking procedure is replicated across the entire planet for each timestep of the model. In this way, moisture can be tracked across the entire planet, simultaneously. 
Table 1. Definitions of key terms used in this research.

\begin{tabular}{ll}
\hline Key term & Definition \\
\hline Moisture recycling & $\begin{array}{l}\text { The process of evaporation arising from the surface of the Earth traveling through the atmosphere and } \\
\text { returning elsewhere as precipitation. }\end{array}$ \\
An area B that is upwind of region A, that provides evaporation for A's precipitation. The extent of \\
precipitationshed is determined by the area that contributes moisture (source region) to a selected region \\
(sink region).
\end{tabular}

We use the backtracking feature of the WAM-2layers (Keys et al., 2012), which allows for the identification of the source region of precipitation - i.e., the precipitationshed. As input to the WAM-2layers, we use ERA-Interim Reanalysis data, from the European Center for Medium-Range Weather Forecasts (Dee et al., 2011). We downloaded global, modellevel data at the $1.5^{\circ}$ by $1.5^{\circ}$. resolution. The WAM-2layers uses 6-hourly data for horizontal and vertical wind, humidity, and surface pressure; it uses 3-hourly data for evaporation and precipitation. The data are interpolated into two levels (an upper and lower level of the atmosphere) to accommodate the upper- and lower-atmosphere processes, namely wind shear (van der Ent et al., 2013), and this separation roughly corresponds to the $800 \mathrm{mb}$ level. We emphasize that the WAM-2layers is a moisture tracking scheme and not a simulation. It is possible to couple the WAM-2layers with dynamic simulations of land-surface hydrology, including vegetation (Wang-Erlandsson et al., 2016; Keys et al., 2016), but that is not what we have done in this research. Thus, the results that we present are based purely on the implicit hydrological information contained within the ERA-Interim Reanalysis data.

Many approaches for precipitationshed boundary selection have been described (Keys et al., 2012, 2014, 2017), and we will employ the $1 \mathrm{~mm}$ boundary as used in Keys et al. (2014). The basis for the $1 \mathrm{~mm}$ boundary in this instance is to have a boundary that is physically meaningful, at least theoretically, in the sense that common rain gauges have a lower limit of $1 \mathrm{~mm}$. Thus, a region that contributes $1 \mathrm{~mm}$ of rainfall is an approximate lower limit for what might be a detectable change in precipitation on a common rain gauge. This $1 \mathrm{~mm}$ boundary refers to a boundary that includes all regions that contribute $1 \mathrm{~mm}$ or more of annual precipitation to the sink region. The precipitationshed is the spatial footprint that we will use in our analysis of the social dynamics among the precipitation sink and its sources of evaporation.

\subsection{Quantifying social features of the precipitationshed}

One approach to capturing the social dynamics of moisture recycling is to characterize various social, economic, and other factors that are biophysically relevant and that can provide insight into the dynamics among the sources and sinks of moisture. In our analysis, we use land use based on anthropogenic biomes data, i.e., anthromes (Ellis and Ramankutty, 2008), food security using the proxy of child malnutrition (Socioeconomic and Data Applications Center SEDAC, 2005), and economic wealth using the proxy of market influence (Verburg et al., 2011) (Table 2). The anthromes data are a land-use classification scheme explicitly developed to account for both the various human uses of landscapes and the density of human populations. For example, rather than having land-use categories that are uniformly "cropland", the anthromes data range from densely populated "rice villages" ( $>100$ people $\mathrm{km}^{-2}$ ), to sparsely inhabited "remote croplands" $\left(<1\right.$ person $\left.\mathrm{km}^{-2}\right)$.

The child malnutrition data represent the number of malnourished children per 1000 under the age of 5 years and is available at the scale of countries (e.g., Russia has a single value) as well as on a subnational scale (e.g., Sudan has many different values). The market influence data are a calculated from a variety of other datasets and are a combination of (1) access to markets (calculated using data on infrastructure, travel distance, and travel costs to major cities) and (2) per capita GDP (for more on calculation, see Verburg et al., 2011). As seen in Table 2, these datasets are 
spatially gridded, at various resolutions. We interpolated the various data to the resolution of the moisture-recycling information (i.e., $1.5^{\circ}$ by $1.5^{\circ}$ ) so that they were comparable with one another in subsequent analyses of the sources and sinks of moisture.

Note, the "source" results (presented in the social characteristics figures, Figs. 2-4), refer to the sources of precipitation excluding the sink itself. In other words, despite the presence of internal moisture recycling, the description of source characteristics do not include the case study country itself.

\subsection{Literature review of social dynamics}

To complement the quantitative characterization of the precipitationsheds, we performed a literature review focused on each of the case study regions (i.e., Mongolia, Nigeria, and Bolivia), exploring potential dynamics that exist among the social, biophysical, and other aspects of the precipitationshed. The literature review is specifically intended to help reveal some of the qualitative, social interactions (e.g., landuse policies, regulatory interactions, economic interlinkages) that may be difficult to uncover in a purely quantitative analysis. We used the hypothetical MRSES concept diagram as a guiding heuristic for how to search for important dynamics.

For each case study, the general approach was to use the precipitationshed as the spatial boundary within which we evaluated the dominant processes governing land-use change and the types of dynamics among the sink region and the source regions. A blend of journal articles, non peerreviewed literature, and web sources provided the key information for building the qualitative description of these social dynamics. The result of the case study analysis is a blend of quantitative and qualitative information, which combined to form a broad-based representation of the social dynamics of moisture recycling for each case study.

\subsection{Construction of archetypes}

System dynamics models expose how different components of a system interact with one another, and they can help reveal the relative importance of different connections and interactions. We distilled the insights from the three case studies into the creation of several MRSES archetypes. The conceptual model presented in Fig. 1 formed the basis of the MRSES and was modified using the case studies.

\section{Results}

\subsection{Mongolia case study}

\subsubsection{Precipitationshed analysis}

In Mongolia, the precipitation source is located in the northern half of the country and along its northwestern border (Fig. 2a). Mongolia provides about $13 \%$ of its own precipitation largely from the northwestern half of the country. Ag- gregated over space (Fig. 2b), the largest moisture contributor of Mongolia's precipitation is Russia (29\%), primarily due to the very large spatial extent of Russia. The only large evaporation contributions originate in the Russian steppe between Kazakhstan and Lake Baikal, and the rest are very small amounts across much of the Russian land surface. The same is generally true of China (13\%), with significant contributions from the Tian Shan to Mongolia's west, and small contributions from the rest of China's land surface. The eastern tip of Kazakhstan is also a key evaporation source region $(9 \%)$, with smaller contributions from the rest of central Asia.

\subsubsection{Social characteristics}

Mongolia is predominantly classified as remote rangeland ( $\sim 80 \%)$ with some populated rangelands and wild barren land (Fig. 2c). Mongolian society is generally quite poor (mean market influence of USD 48.40 per capita), with relatively high child malnutrition (around $12 \%$ or 120 in 1000 children) (Fig. 2d). Most of Mongolia's key evaporation sources are rangelands (within and outside Mongolia), as well as wild and remote woodlands. The societies in Mongolia's source regions are on average richer (market influence of USD 2279.50) and experience less hunger (5.6\%).

\subsubsection{Literature review of social dynamics}

Mongolia's precipitationshed includes significant contributions from internal recycling within Mongolia, as well as significant contributions from the East Siberian taiga to the north, the steppes in Kazakhstan, and Xinjiang province in northwestern China. Mongolia's land-use policy has had several distinct phases of management in the recent past, with traditional management of grasslands via customary nomadic herder institutions, then with the negdel "pastoral cooperative" policy, followed by post-negdel policies largely dependent on local government management (Ojima and Chuluun, 2008). The transition from widespread mobility of herders to much more confined mobility (in large part due to expansion of agricultural lands) has led to significant changes in land water use. Recent analyses find that if present trends of agricultural expansion continue, then water shortages may become common (Priess et al., 2011). Similarly, if irrigated agriculture continues for a significant period of time and soils are not drained properly (as has happened throughout much of Inner Mongolia in China), then it is possible that soils and landscapes will become salinated and less able to sustain vegetation (Kendy et al., 2003). The segmentation of Mongolia's traditionally managed grassland landscapes into grazing land and agricultural land and the associated fragmentation or prohibition of seasonal movements of livestock may lead to significant land-use change in the near future.

Kazakhstan, to Mongolia's west, provides a significant amount of moisture especially from its northern steppes, 
Table 2. Summary of metadata for anthromes, child malnutrition, and market influence data.

\begin{tabular}{|c|c|c|c|c|c|}
\hline $\begin{array}{l}\text { Variable } \\
\text { name }\end{array}$ & Description & $\begin{array}{l}\text { Source } \\
\text { resolution }\end{array}$ & Units & $\begin{array}{l}\text { Time } \\
\text { period }\end{array}$ & Source \\
\hline Anthromes & $\begin{array}{l}\text { anthropogenic biomes, incl. } \\
\text { type of human land use } \\
\text { and population density }\end{array}$ & $5 \operatorname{arcmin}$ & categories & 2000 to 2005 & $\begin{array}{l}\text { Ellis and Ramankutty } \\
\text { (2008) }\end{array}$ \\
\hline $\begin{array}{l}\text { Child } \\
\text { malnutrition }\end{array}$ & $\begin{array}{l}\text { the number of children under } \\
5 \text { years of age, who are } \\
\text { malnourished, per } 1000 \text { children }\end{array}$ & $\begin{array}{l}\text { subnational } \\
\text { or national }\end{array}$ & no./1000 & 2005 & $\begin{array}{l}\text { Socioeconomic and Data } \\
\text { Applications Center } \\
\text { SEDAC (2005) }\end{array}$ \\
\hline $\begin{array}{l}\text { Market } \\
\text { influence }\end{array}$ & $\begin{array}{l}\text { per capita GDP multiplied } \\
\text { by market access (e.g., composite } \\
\text { of travel distance, time, etc.) }\end{array}$ & $5 \operatorname{arcmin}$ & USD/person & $\begin{array}{l}2010 \text { (per cap GDP), } \\
1979-2005 \\
\text { (market access) }\end{array}$ & Verburg et al. (2011) \\
\hline
\end{tabular}

and from the Altai and Tien Shan. Following the collapse of the Soviet Union, Kazakhstan's livestock population decreased significantly, with a concurrent reduction in grazing land pressure (Robinson et al., 2003). This change in grazing pressure has led to the replacing of previously grazed land with other grasses and weedy species during fallow periods and importantly has led to detectable changes in vegetation and hypothesized changes in near-surface meteorology (De Beurs and Henebry, 2004). This has direct implications for evaporation and subsequently moisture recycling.

In terms of politics, the ascendent Mongolian People's Party has strong ties to Russia's Vladimir Putin, suggesting that political and diplomatic levers of power may flow not through adjacent China but rather north to Russia (Jargalsaikhan, 2017). Likewise, Mongolia is currently experiencing significant crises with regard to its management of debt, and thus it is beholden to both international lending agencies, as well as the international mining conglomerates fueling its development. Though Mongolia is reliant on China for export goods (China is the recipient of $79 \%$ of Mongolia's trade by volume), China is not reliant on Mongolia in nearly the same way (Simoes and Hidalgo, 2011). Likewise, Mongolia relies on imports from China and Russia in nearly equal measure (31 and $26 \%$, respectively) (Simoes and Hidalgo, 2011). Aside from mining concessions and the associated resource use, these political and economic connections are not directly linked to large-scale land-use change but rather to the underlying conditions and connections that might provide a motivation (or lack thereof) for managing land use in a manner that is most sustainable for moisture recycling, specifically, and water resources, generally.

To summarize, Kazakhstan's abandonment of former grazing land, the low level of land-use change in the East Siberian taiga, and the isolation of the Altai and Tien Shan regions suggest relatively low social connectivity from source to sink. Likewise, given the fact that Mongolian institutions are stronger (than, e.g., in Kazakhstan and in Xinjiang) and that the departure from historic land use and land management is more pronounced in Mongolian grasslands, we suggest that the social connections are strongest within Mongolia itself, leading to a somewhat isolated state of precipitationshed social connectivity.

\subsection{Niger case study}

\subsubsection{Precipitationshed analysis}

In Niger, the precipitation source is concentrated along the southern border (Fig. 3), with a moisture supply plume fading towards the south. Niger supplies just $9 \%$ of its own moisture, but because of the large number of neighboring countries, this percentage suffices to make Niger top the list over other moisture suppliers. There is significant contribution from Nigeria to the south $(6 \%)$ and Chad $(6 \%)$ and Sudan $(5 \%)$ to the east. There is some contribution from the Democratic Republic of the Congo, the Central African Republic, and South Sudan (all 2\%). Beyond that, there is diffuse contribution from some West African countries. Our method detected some contribution from the Mediterranean Sea, but this is likely spurious and due to the inability of moisture tracking models such as the WAM-2layers (as well as other a posteriori tracking models) to disentangle the origin of moisture convergence in this region, specifically the mixing of dry air from the north with moist air from the south.

\subsubsection{Social characteristics}

Land use in Niger is predominantly "wild barrens", given that much of its land surface is in the Sahara. Among the populated anthromes, Niger is equally distributed among rainfed croplands, rangelands, and inhabited (i.e., very low population density) barren lands. Residential rainfed crops are a dominant anthrome type among Niger's moisture sources, along with some rangelands and woodlands. Niger's hunger and wealth characteristics are different from its source countries with the mean values of USD 49.20 per capita market influence and $40.2 \%$ child malnutrition, barely within the standard deviation of the societies in its evaporation sources. The average market influence among Niger's sources is USD 4081, with a very wide standard deviation ranging from 
(a) Mongolia precipitationshed

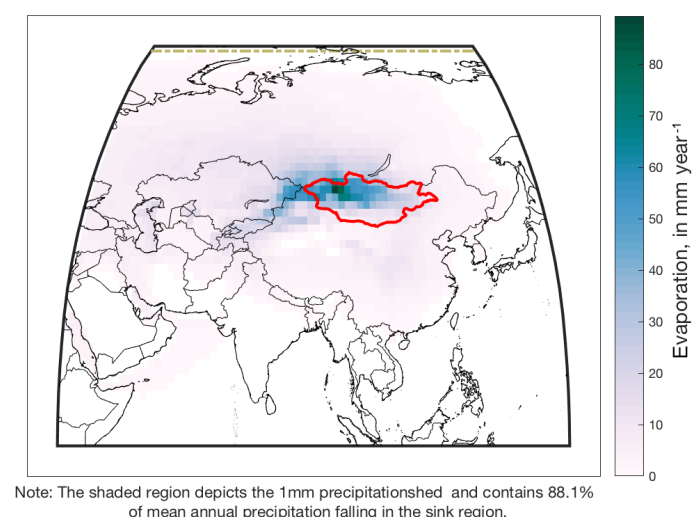

(b) Origin of precipitation by nations

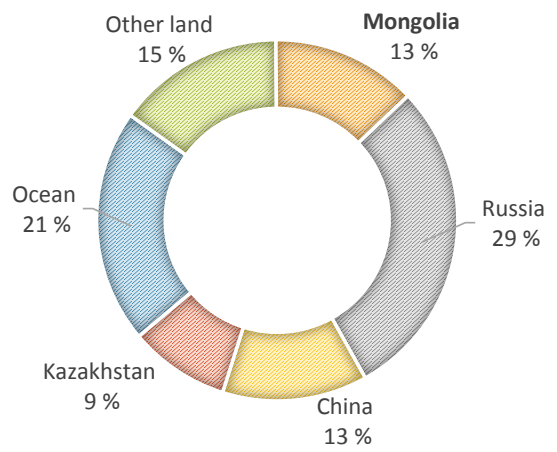

(d) Hunger and wealth in Mongolia case study

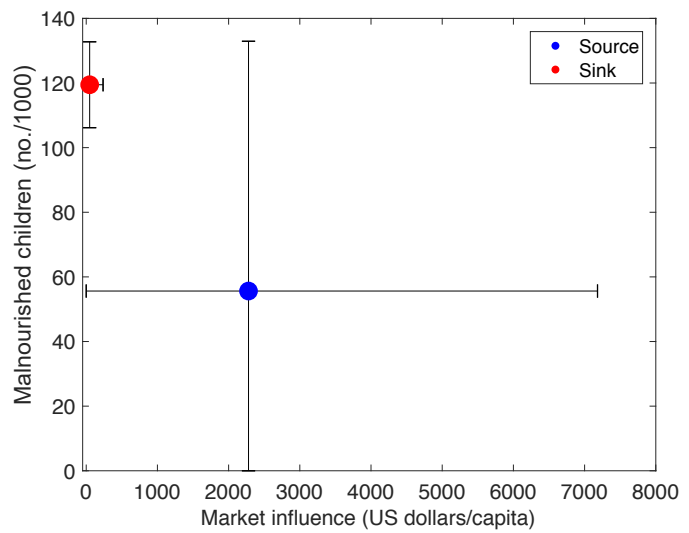

Figure 2. Mongolia case study including (a) precipitationshed analysis, (b) key source countries, (c) comparison of land uses between the country and its precipitationshed, and (d) comparison of economic and food security aspects of country and source regions.

nearly USD 0 to more than USD 11000 . Likewise, the mean child malnutrition is $23.8 \%$ with a standard deviation from a high of $40 \%$ to a low of around $7.5 \%$.

\subsubsection{Literature review of social dynamics}

Within Niger, land-use change over the last several decades has seen increases in cropland cover (where possible) with corresponding decreases in fallow land (Hiernaux et al., 2009). The ownership of land, i.e., land tenure, in Niger has historically been governed by customary systems administered by communal chiefs. However, in the mid-1980s there was a push to formalize land tenure via governmentsponsored registration efforts, especially in rural areas of Niger (Toulmin, 2009). This process led to large-scale confusion in part due to poorly executed policies, underfunded and understaffed government agencies, and unintended entrenchment of rural power hierarchies (Benjaminsen et al., 2009). Thus, current land tenure in Niger is working towards clearer ownership and tenure yet remains challenged by underfunded institutions and intractable overlapping claims of ownership. Also, Niger has not been subject to the global phenomena of land acquisitions (a.k.a. land grabs, largescale land acquisitions), perhaps as a result of low rainfall overall, slowly improving land tenure, or a lack of available land.

Directly to the south, Nigeria provides a considerable fraction of Niger's rainfall and has a uniform, national land-use policy (i.e., the Land Use Act), which essentially grants the authority of land ownership to the governor of each Nigerian state (Damilola, 2017). This was originally meant to avoid problems of land speculation and overlapping or competing claims of ownership and provide protection against foreign interference with land issues. However, the current issue of land acquisitions by foreign entities, often for large amounts of money, makes this process of land ownership vulnerable to corrupt leaders (Damilola, 2017). Currently, Nigeria has ex- 
(a) Niger precipitationshed

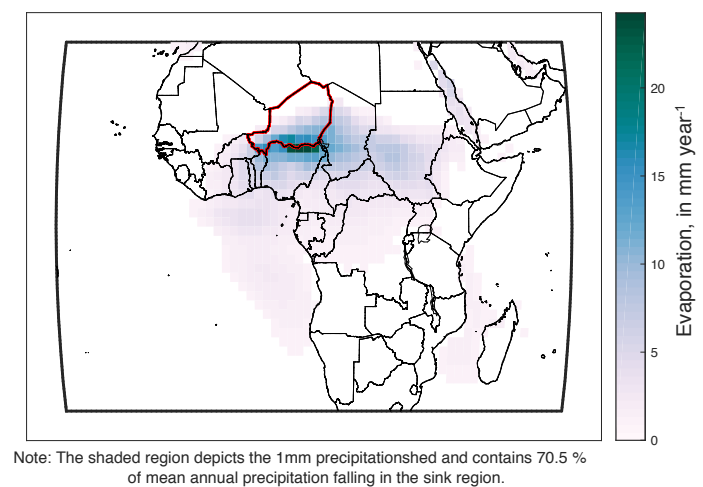

(c) Distribution of anthromes in Niger case study

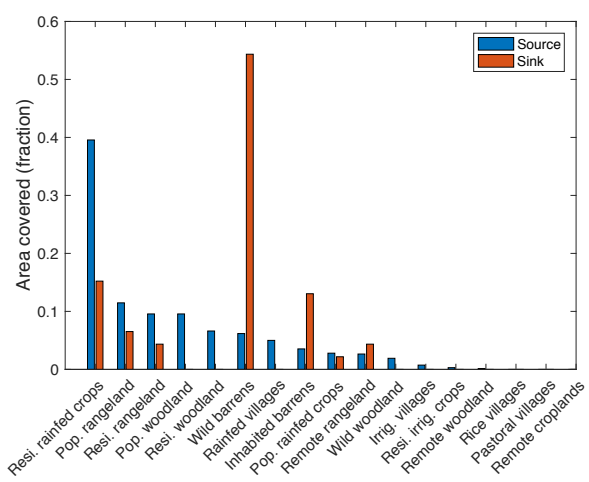

(b) Origin of precipitation by nations

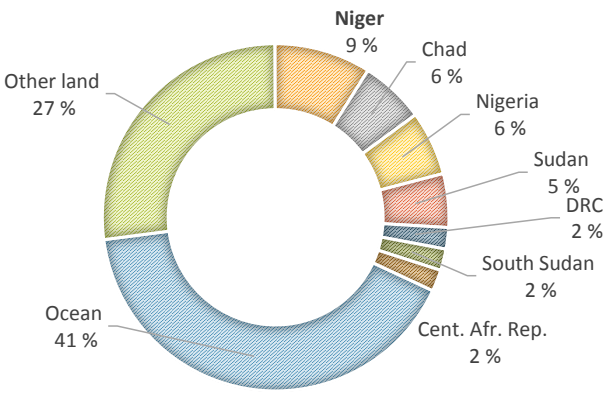

(d) Hunger and wealth in Niger case study

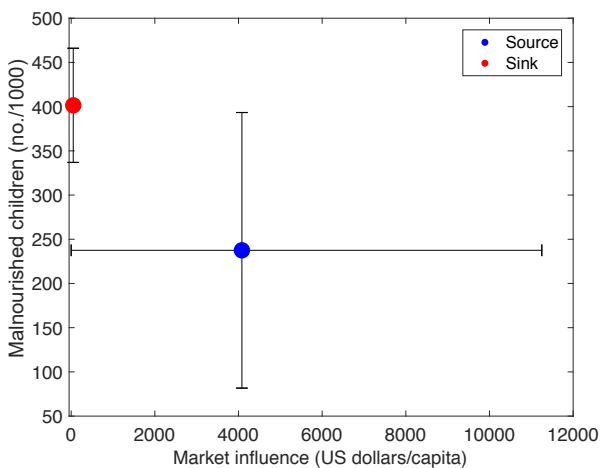

Figure 3. Niger case study including (a) precipitationshed analysis, (b) key source countries, (c) comparison of land-uses between the country and its precipitationshed, and (d) comparison of economic and food security aspects of country and source regions.

perienced many such land acquisitions and is among the top 20 nations globally involved in land acquisitions (Osabuohien, 2014). This is relevant primarily because significant areas of land (estimated at $~ 265000$ ha in LandMatrix, 2018) suggest extensive potential modification of the land surface, with associated impacts on moisture recycling.

Chad, located to the east of Niger, provides around $6 \%$ of moisture but suffers from chronic poverty. Reliance on agriculture or livestock rearing provides $80 \%$ of Chadian employment, but open-access policies for land have led to overgrazing and inadequate management has led to deforestation and desertification around dense population centers. These dynamics contribute to an uncertain and rapidly changing land-use regime in Chad (Walther, 2016; USAID, 2010). Sudan, like Chad, is also experiencing rapid land-use change, though with more-pronounced land-tenure insecurity and the ability of centralized government to lease land without consulting local communities. Sudan has been a key target of land acquisitions, leading to internal conflict and potentially displaced persons. As with Chad, there is high potential for unpredictable land-use changes including both increased evaporation from agricultural expansion and desertification from unsustainable land and water management (USAID, 2013).

Niger's primary trading partners are France, Thailand, Malaysia, and China, with Nigeria the only notable regional trade partner. France is the destination and origin of more than $30 \%$ of both exports and imports. Regionally, Nigeria is the destination of $9.5 \%$ of Niger's total export volume, primarily in the form of refined petroleum. Similarly, Niger receives about $5.8 \%$ of its total imports from Nigeria, primarily in the form of cement, electricity, and tobacco. Niger, however, represents a tiny trade partner for Nigeria, providing only $0.25 \%$ of Nigerian imports and $0.18 \%$ of Nigerian exports. Beyond this, Chad and Sudan are very poorly integrated in terms of total trade volume with Niger and Nigeria. Thus, the countries in this region appear to be much more economically tied to countries outside the region than within the region. Overall, this suggests limited regional economic integration.

To conclude, the rapid land-use change taking place in many parts of Niger's precipitationshed suggests there is a high potential for change in moisture recycling driven by social-ecological processes. The ability to influence one an- 
(a) Bolivia precipitationshed

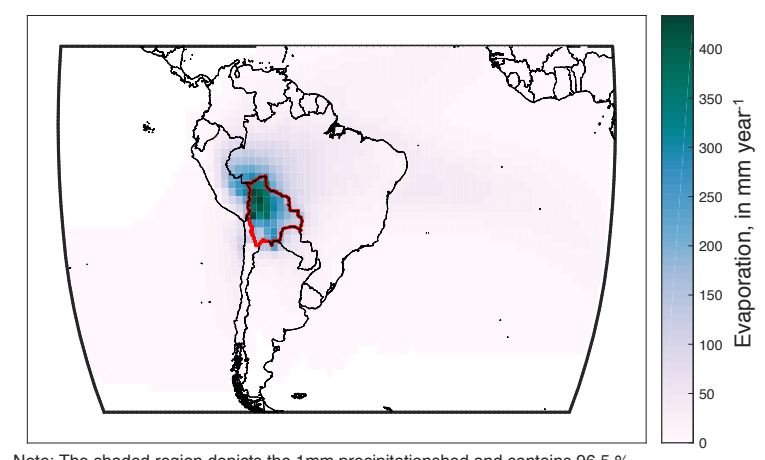

of mean annual precipitation falling in the sink region.

(c) Distribution of anthromes in Bolivia case study

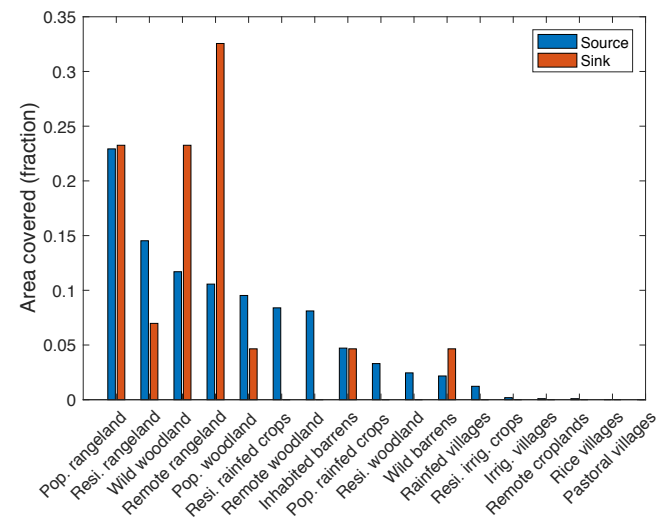

(b) Origin of precipitation by nations

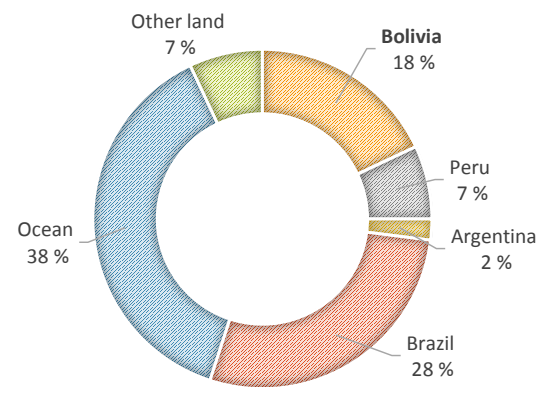

(d) Hunger and wealth in Bolivia case study

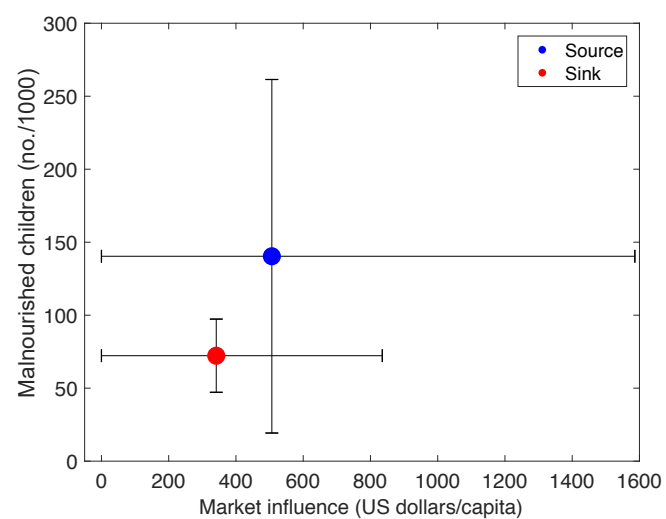

Figure 4. Bolivia case study including (a) precipitationshed analysis, (b) key source countries, (c) comparison of land uses between the country and its precipitationshed, and (d) comparison of economic and food security aspects of country and source regions.

other's land use, and subsequently moisture recycling, is thus possible. However, active coordination among key sources in Niger's precipitationshed is relatively low. Some international institutions, such as the International Water Management Institute's Water Land and Ecosystems programme, enable some trans-boundary policy coordination on key water and ecosystem issues (Saruchera and Lautze, 2015). Meanwhile, other types of activities, such as Forest Stewardship Council certifications, have considerably less influence (Nasi et al., 2012; Malhi et al., 2013). The pace of land-use change, the dense and growing dynamism of populations in all nations in Niger's precipitationshed, and the mixture of internal and external policy effectiveness suggest a medium level of social connectivity.

\subsection{Bolivia case study}

\subsubsection{Precipitationshed analysis}

In Bolivia, the source of the precipitation is distributed across the country, with a slight concentration in the north (Fig. 4). Despite the high concentration of moisture supply sources within the country, Brazil is the most important moisture sup- plier thanks to both a high concentration of moisture supply just north of Bolivia's border in the Acre region and to the remainder of Brazil supplying a low concentration of moisture from a large area. The Peruvian Amazon is also an important contributor, as is the extreme north of Argentina.

\subsubsection{Social characteristics}

Bolivia's anthromes are more than $50 \%$ rangelands and a little more than $25 \%$ woodland, i.e., the Amazon. The key source areas are the Amazon in Brazil and Peru, but broadly speaking, Bolivia's precipitationshed includes a high fraction of rangelands (about $50 \%$ ). Rainfed croplands comprise much of what remains (about 10\%). Bolivia is characterized by relatively low child malnutrition (mean of $7.2 \%$, with a standard deviation ranging from 5 to $10 \%$ ) and market influence of USD 341, ranging from just above 0 to more than USD 800 . This is not very wealthy compared to some regions, but it is considerably better off than other regions' chid malnutrition (especially that of the Niger case study). Bolivia's sources of moisture are characterized by societies with higher mean malnutrition $(14 \%)$ and higher wealth 
(USD 506), though the standard deviation exceeds all of Bolivia's values. This means that in terms of the standard deviation, Bolivia's social characteristics are well within the range of the societies in its precipitationshed.

\subsubsection{Literature review of social dynamics}

Bolivia's precipitationshed includes key contributions from within Bolivia itself, from Brazil, and from Peru. The dominant land uses throughout the key source regions are rangelands and forests. The strength of land-use management, in terms of governance effectiveness varies among these three nations, as does the level of land-use change, ranging from well-developed land-use methods (such as in Brazil) to much lower impact, though with high potential (as in Peru). Bolivia itself generates $18 \%$ of its own rainfall, primarily from tropical forests, the Pantanal wetland, and rangelands. Historically, Bolivia's government has had a strong control on the protection of forests from change, such as the first "debtfor-nature swap" in 1987 (Hansen, 1989). These, and other projects such as REDD and REDD+ projects aimed at keeping forests intact, have also been criticized for simply leading to "leakage" of land-use change to other regions, either within Bolivia or beyond its borders (Verweij et al., 2009).

In adjacent Peru, the key forested areas that could change, and thus lead to changes in moisture recycling, are very difficult to access, yet as population migration to the Peruvian Amazon is high, the current rate of deforestation is steadily increasing (Perz et al., 2005). Many overlapping jurisdictions and leases both among owners of land, as well as owners of different types of resources (e.g., timber, land, minerals, and fossil fuels), have led to contentious claims of ownership (Finer et al., 2008; Killeen et al., 2008). Additionally, recently built roads from Brazil through southern Peru will likely spur greater development of the region. A key challenge is that Brazil's land-use regulations and enforcement are stronger than Peru's, leading to the leakage of deforestation activity, primarily for the expansion of cattle grazing land.

Land-use policy in Brazil is quite strong, at least on paper. However, the regulatory environment is inconsistent, and the enforcement strongly depends on which political party is in power (Hurrell, 1991). According to Brazil's Forest Code, the central policy regulating deforestation, land owners are required to keep $80 \%$ of occupied land as forest, but enforcement of this is difficult (Perz et al., 2005). Importantly, the key source regions of Bolivia's moisture are in the Acre region of Brazil, which is quite remote and under considerable existing deforestation pressure (Kainer et al., 2003). Notably, there is a stark contrast between existing deforestation patterns in Brazil (especially in Acre and Rondônia states), relative to deforestation in Bolivia and Peru. Also, deforestation in Brazil is rising again, after years of successful implementation of anti-deforestation policy.
The quality and strength of land-use policy within these three countries is strongly tied to both national-level policy, as well as participation in international land-use management efforts (e.g., REDD+), along with international trade efforts (e.g., Forest Stewardship Council certification) (Killeen et al., 2007). As a result, this region's actual land-use management exhibits a wide range of effectiveness, despite many controls in place to avoid large-scale change. Land-use change leakage (Verweij et al., 2009) is more difficult to control; thus, the feedbacks of strong policies within countries may lead to other problems, especially if one of these three nations becomes more vulnerable to land-use change leakage from internal changes, due to management decisions in an adjacent country. In addition to historic trends in land-use change, recent evidence suggests a large shift is taking place in Amazonian deforestation away from Brazil to Bolivia and Peru. This is driven by several factors, including the opening up of Peru's interior via new transport networks, the moratorium on soya cultivation in Brazil, and previous deforestation estimates not accounting for small-scale and artisanal deforestation (Kalamandeen et al., 2018).

Bolivia's dominant exports are fossil fuels (45\%) and minerals (zinc, precious metals, lead, gold, etc., nearly $30 \%$ ) (Simoes and Hidalgo, 2011). Bolivia's dominant export to Brazil is natural gas ( $97 \%$ of exported trade flow to Brazil), and this represents $48 \%$ of Brazil's natural gas imports (Simoes and Hidalgo, 2011). In terms of trade, this is the largest trade flow between these nations and is facilitated by pipelines connecting to Brazil. Given the dependence of Bolivia on natural gas exports to Brazil for its economy and Brazil's dependence on Bolivian natural gas, this interdependency could be a basis for cooperation on other topics such as land-use policy around natural gas reserves and pipelines, particularly the leakage of Brazilian deforestation.

The shared issues of deforestation in Peru, Brazil, and Bolivia, as well as strong legacies of deforestation policy in Bolivia and Brazil, suggest a relatively strong institutional capacity for managing change. Likewise, the economic connection, albeit in the form of natural gas pipelines connecting Bolivia to Brazil, suggests a reliable economic connection (Finer et al., 2008). Additionally, the strong engagement of Bolivia's source regions in international programs targeting land-use change (e.g., REDD+, FSC) implies a social tele-coupling beyond the precipitationshed that directly interacts with land-use policy. Finally, the international drivers of land-use change, especially in Brazil regarding soya cultivation, suggests global-scale social connections (Flach et al., 2016). Thus, we suggest Bolivia and its precipitationshed experience strong internal social coupling, as well as global tele-coupling.

\subsection{Construction of archetypes}

Based on the results from case study analysis, we see three basic patterns of social dynamics in moisture-recycling sys- 


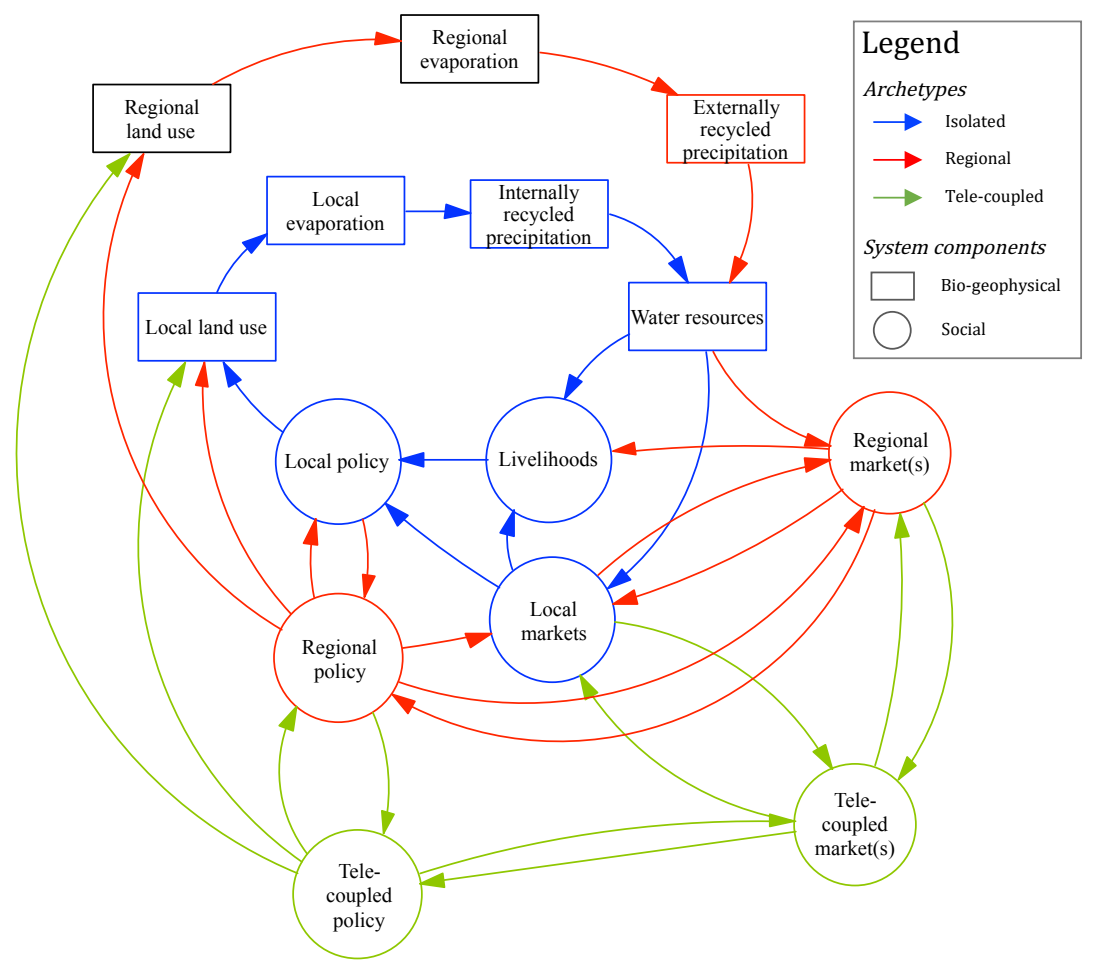

Figure 5. Archetypes of moisture-recycling social ecological system (MRSES), with blue corresponding to "isolated", red to "regional", and green to "tele-coupled".

tems: (1) an isolated system archetype, dominated by internal processes; (2) a regional archetype linking adjacent countries; and, (3) a tele-coupled archetype that links precipitation sink regions with regions outside the precipitationshed boundaries (Fig. 5). Where we refer to policies that could interact with moisture recycling, we refer to potential moisturerecycling governance (potential policies, etc.), and not to existing moisture-recycling governance. Also, we explicitly excluded some information from Fig. 5, such as material versus immaterial links, since the emphasis for this figure was on the archetype distinction rather than the links themselves.

The core structure of each archetype is empirically grounded, given that it is well-understood that land-use change directly affects evaporation, with increased vegetation typically increasing evaporation and decreased vegetation typically decreasing evaporation (Gordon et al., 2005; Wei et al., 2013; Spracklen and Garcia-Carreras, 2015). Likewise, changes in evaporation can have direct influences on the moisture recycling that returns locally (Badger and Dirmeyer, 2015; Lawrence and Vandecar, 2015). This is true for sources of evaporation flowing to a sink region, as well as recycling within a sink region itself. This precipitation then provides water resources to local livelihoods, including both subsistence agriculture as well as "off-farm ecosystem services" such as livestock forage and timber (Ojima and Chuluun, 2008; Descheemaeker et al., 2011).
How well people are doing (e.g., whether they are hungry or not) will inform the decisions they make about further modifications to the landscape (Rockström et al., 2002; Enfors, 2013), such as increasing labor and investment to maintain crop yields or foregoing labor and investment with coincident decreases in crop yield and possibly land abandonment (Mortimore and Tiffen, 1994). Local land-use policy is formulated and implemented at least partially in response to rainfall changes. These policies are based tacitly on the confidence and knowledge of precipitation patterns and moisturerecycling feedbacks as well as on how the benefits and negative impacts are distributed among different social groups (Roncoli et al., 2002). Finally, these decisions may include further land-use change or regrowth of natural land, strengthening or weakening the feedback loop.

\subsubsection{Isolated archetype}

The "isolated" archetype is the simplest of the proposed MRSESs. In terms of social dynamics actively driving change in the precipitationshed, Mongolia is isolated. In the isolated archetype, we draw attention to the fact that there are few connections or feedbacks beyond local government or with other regional actors (Fig. 5, blue arrows). The large contributions from China and Russia are so diffuse that the social processes driving the evaporation are unable to be meaningfully discussed. Likewise, the diffuse evapora- 
tion contribution from Russia is predominantly coming from the Siberian taiga which has not experienced much land-use change. If anything, there has been moderate reforestation from post-Soviet land abandonment (Meyfroidt et al., 2016), but in the regions relevant to Mongolia this has been minimal.

\subsubsection{Regional archetype}

As the social connections between different sources and sinks become more numerous, regional interactions emerge (Fig. 5, red arrows). For instance, Niger experiences some recycling but also relies on contributions from neighbors in Nigeria, Chad, and Sudan. Likewise, all of these countries have active, socially driven land-use change taking place that is impacting evaporation rates (Savenije, 1995; Foley et al., 2003; Tschakert, 2007; Salih et al., 2013). The regulatory regime in these four countries varies considerably, ranging from corrupt to fair and from decentralized to centralized.

To generalize, as the importance of internal moisture recycling decreases, the activities of key source regions ought to be considered. Where the rule of law is present, changes in regional evaporation could be related to government regulations or policies that serve to influence how land-use change unfolds. However, in more lawless regions where governance and institutions are absent or corrupt, large-scale land-use change is typically driven by national or international corporate actors (Galaz et al., 2017). In this archetype, we see the addition of an external driver, notably "regional policies" and "regional markets". Essentially, we are highlighting the fact that the inner loop is now connected to regional actors, since regional land-use changes affect moisture recycling and the subsequent social aspects of the core feedback loop. Notably these actors are spatially connected, e.g., within the same precipitationshed or in adjacent countries. We also illustrate how regional interactions can more directly drive changes in external moisture recycling. Other key differences between the isolated and "regional" MRSESs, are additional moisture-recycling interactions with regional markets, land management, and policy. Specifically, regional and subregional actors have feedbacks among themselves and with "local" livelihoods, markets, and policy nodes.

\subsubsection{Tele-coupled archetype}

The third MRSES is "tele-coupled", and this structure draws attention to the spatially disconnected, i.e., tele-coupled, actors that can influence the social connections in the central, regional, or tele-coupled feedbacks (Fig. 5, green arrows). Bolivia, which relies on rainfall from Brazil for nearly half its rainfall, would seem to be a regional archetype, were it not for the dense connections to global forest conservation, deforestation driven by developed nations, and transnational agribusiness present in Bolivia, Peru, and Brazil (Galaz et al., 2015; Flach et al., 2016). These tele-coupled actors can drive land-use change in the precipitationshed, but these actors are not directly impacted by any changes in the land use aside from perhaps changes in export commodities. Also, these tele-coupled actors are not necessarily affected by the consequences of any changes to internal moisture recycling (though they can be), while nonetheless driving changes in the MRSES itself.

\section{Discussion}

\subsection{MRSES archetypes are idealized}

Our analysis ends up with three archetypes that are idealized in structure and interaction. However, there are situations where certain aspects of the archetypes as they are represented may actually be at odds with one another. For example, in Fig. 5 the policy nodes are uniformly going towards land use. However, there is no distinguishing how local policies might be at odds with regional or tele-coupled policy (e.g., local efforts to discourage deforestation could be hindered by national policies encouraging the settlement of rural forested areas). Additionally, there is greater uncertainty associated with the social nodes (Fig. 5, circles) of the MRSES archetypes than with the bio or geophysical nodes (Fig. 5, rectangles). This is partly because there has been much more study devoted to understanding the geophysics of moisture recycling, relative to the social dynamics of moisture recycling.

The archetypes themselves are also idealized in that they are depicted as separate, distinct systems. Yet, in reality, they are likely to exist along a spectrum from isolated to tele-coupled. Thus, for example, in moving from isolated to regional, the MRSES might first integrate the regional moisture-recycling components and then begin incorporating regional markets, regional policy, etc. The spectrum of the MRSES from isolated to tele-coupled is not meant to convey any sort of desirability one way or another; each has benefits and disadvantages. For example, in an isolated case with intense contributions from nearby regions, there is a greater concentration of risk from accelerating feedbacks, such as local forest clearing reducing evaporative flow to the atmosphere, thereby leading to a positive feedback of less moisture available for local rainfall and subsequent impacts on vegetation. Conversely, diffuse contribution suggests less risk from a single location but concomitantly less possibility to manage or influence land use.

\subsection{Guidelines for constructing MRSES}

In this work we only examine three case study regions that roughly correspond to three archetypes, yet we are able to provide some guidance for the construction of additional archetypes using our method. First, it is important to note the number of countries providing significant evaporation contribution (i.e., a few or many), in which social processes 


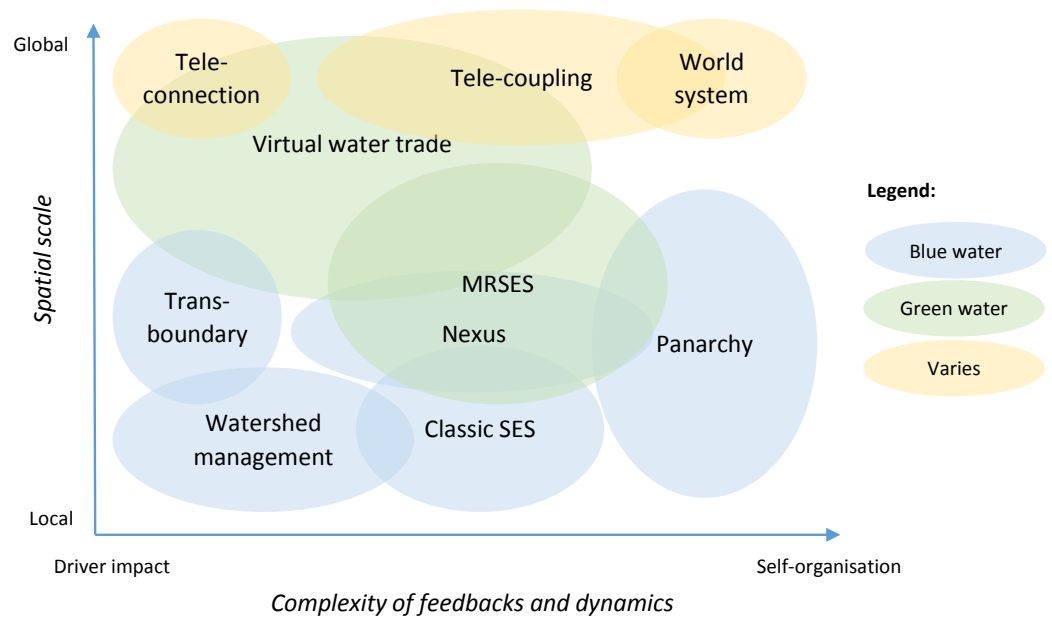

Figure 6. Concept of MRSES in relation to other concepts pertinent to human-water system research along the axes of spatial scale and feedback complexity considered and in terms of water flows considered. Blue water refers to liquid water in rivers, lakes, and aquifers, whereas green water here refers to terrestrial evaporation and moisture flows.

are driving rapid land-use change. Second, the precipitationshed can have low or high connectivity to global markets. When combined, these two classifications would make four archetypes. However, we suggest only three archetypes, since global market connectivity will make a MRSES telecoupled regardless of whether there is one country where social processes are important (e.g., Mongolia) or many countries (e.g., Niger). In other words, once a country crosses the threshold from being disconnected to connected to global markets, it moves inexorably from being either isolated or regional to tele-coupled. Furthermore, this dynamic is unlikely to be reversed given the momentum and increasing networked complexity of global markets and institutions, with notable exceptions, such as post-Soviet nations.

\subsection{Advancing human-water system understanding}

The proposed MRSES framework offers a new conceptual lense to delineate system boundaries in regions where moisture recycling and human land-use decisions are substantial in comparison to other dynamics at play. This complements the various frameworks, theories, and mental models that have been developed for understanding human-water systems in terms of spatial scale, complexity of dynamics, and part of the water cycle considered (Fig. 6).

As illustrated in Fig. 6, some of the most important conceptual system boundaries considered in water management research include (increasing in scale and complexity) watershed (Giordano and Shah, 2014), transboundary river basin (Giordano and Shah, 2014), nexus approach to account for synergies across sectors (Endo et al., 2015), and concepts of water footprint and virtual water that account for the trade of embedded water (Allan, 1997). The typical classical SES concept (Holling, 2001; Folke et al., 2004; Folke, 2006) and panarchy (Gunderson and Holling, 2002) has typically con- sidered social dynamics more profoundly but has also mainly been limited to blue water (i.e., river flows, groundwater, lakes) (Gunderson et al., 2017). In land system science, teleconnection has been used to describe remote drivers of landuse change, and tele-coupling has been used to describe multidirectional feedbacks (Friis et al., 2016), of which water has been considered a link through, e.g., virtual water and land acquisition (Johansson et al., 2016). Other holistic concepts include world system analyses (Gotts, 2007), system integration (Liu et al., 2015), and planetary boundaries (Rockström et al., 2009; Steffen et al., 2015), which while allencompassing, tend to have weak local to regional perspectives of operationally policy-relevant human-water interactions.

Thus, the MRSES concept, while lacking the crosssectoral or holistic perspective in comparison to nexus or world system approaches, fills a conceptual gap by accounting for social feedbacks and atmospheric moisture flows with a consideration of local to regional scale socioeconomic dynamics and policy processes. Potentially, MRSES could be woven into large-scale hydrological modeling or form part of a hydro-economic model, in addition to other human interference such as irrigation, inter-basin transfer, and virtual water (Wada et al., 2017). In especially moisture-recyclingintense regions, MRSES could also be considered for analyzing complex coevolutionary systems, as distilled conceptualization can be useful for exploring such dynamics (Thompson et al., 2013).

\subsection{Systems may be reinforced in unexpected ways}

The MRSES archetypes we propose all exhibit some complexity and increase in complexity when moving from isolated to tele-coupled. Complexity indicates the potential for surprises induced by feedbacks (Levin et al., 2013). This 
is most apparent in the local and regional land-use change policies since those simultaneously have the strongest policy influence and affect regions with the highest moisturerecycling values. For example, the consequences of policy decisions to graze the Kazakh steppe and then the abrupt abandonment of this grazing changed the moisture-recycling dynamics and potentially the rain falling in Mongolia.

A notable feature is the role of tele-coupled, spatially disconnected actors for driving change in the precipitationshed. For example, the change in the spatial distribution of Amazonian deforestation, i.e., in Peru and Bolivia, is apparently driven by palm oil and soya cultivation in Peru and Bolivia (Kalamandeen et al., 2018). This is further emphasized in our discussion of soya-related deforestation in Brazil and how international agribusiness interests with regard to soya cultivation, combined with Brazil's soya moratorium, are pressuring deforestation leakage into Bolivia (Flach et al., 2016; Kalamandeen et al., 2018).

Additionally, the relationships we identified as potentially existing in the system underline the reality that the system has different kinds of leverage points. For example, in the feedback loop of the isolated archetype, where policy influence and moisture recycling are tightly interconnected, there is potential for faster change but also for more immediate intervention. Conversely, the geophysically separate, socially tele-coupled drivers of land-use change can influence a region's rainfall, while the recipients of that rain have much less of an ability to influence those tele-coupled drivers of change. Moreover, the tele-coupled international actors have the potential to influence both economic policy in the sink region as well as apply market pressure to societies that are regulating rainfall. All the while these tele-coupled actors experience very little feedback from the moisture-recycling system, aside from indirect changes to, e.g., commodity crops. All of these different dynamics suggest that a portfolio of governance strategies will be necessary to address different kinds of challenges (see more on institutional challenges in Keys et al., 2017).

\subsection{Power must be considered carefully}

Though our analysis of the relationship between moisture recycling, wealth, and hunger has been simplified (e.g., Figs. 2d, 3d, 4d), we highlight a few key considerations with regard to power and equity in MRSES. First, in isolated MRSESs (e.g., Mongolia) there can still be a wide range of social characteristics (e.g., in wealth and malnutrition). The ability to affect land-use change policies that are impacting terrestrial moisture recycling may be distributed similarly. Thus, inevitably, some groups of society will have more of an ability to influence land-use change and moisture recycling, while others may simply be impacted by these changes. This sort of imbalance in control and power over resources ought to be considered.
Second, as MRSESs expand to include more than one country, the potential for some parts of society within the MRSESs to have more control over others may become more complex, and furthermore, the political power balance among nations becomes more important. In the Bolivia and Niger cases, the ability of precipitationshed nations to drive change (e.g., Brazil for Bolivia and Nigeria for Niger) begins to matter. Moreover, in tele-coupled systems, international and non-state actors can begin driving significant terrestrial moisture-recycling change, for example by interference (or control) of land-use change on commodity prices. This sort of relationship has been noted in other work as well, such as the ability of Chinese land-use decisions to impact North Korean precipitation (Wei et al., 2013).

Other work has suggested the importance of existing institutions for governing moisture recycling (Keys et al., 2017), but difficult questions have yet to be answered, e.g., "who gets to change the rain?" In many poor countries and regions, land-use change is a necessary part of subsistence and survival. Acknowledging a need for fairness, equity, and perhaps a right to modify terrestrial moisture recycling (e.g., by indigenous people) may be an equitable component of moisture-recycling governance. Fundamentally, this analysis suggests that as Earth system scientists continue to make strides in understanding moisture recycling and its impacts, it will be vital to acknowledge how the benefits or costs are distributed through society. Transboundary water management, can offer useful lessons and warnings regarding tradeoffs among upstream and downstream users. For example, recent analysis of hydropower on the Mekong River has revealed major gaps in how upstream and downstream users are considered, particularly in terms of what is equitable (Grumbine et al., 2012). The study of water justice and governance is an active discipline (Neal et al., 2014), and if MRSESs are explored further, we hope that justice and equity form an integral part of that research.

As we move forward as a scientific community, and potentially if the concept of precipitationshed gains traction in the practitioner community, it will become increasingly important to have tools that allow us to answer questions related to justice, equity, and livelihoods. Interdisciplinary scientists, especially those trained in the natural sciences, ought to learn to recognize the potential pitfalls of a limited scientific worldview. For example, natural scientists are often "positivist", meaning they assume that a meaningful assertion ought to be scientifically verifiable and provable logically or mathematically. This is not the worldview of much of the social science community, let alone in the practitioner community or the broader public. An awareness of the diversity of scientific worldviews is critical for successfully addressing inherently value-based questions (i.e., normative questions). At a core level introspection is prerequisite for evaluating the questions being asked and how those questions are posed. 
Furthermore the hydrological description of sources and sinks of atmospheric moisture is inherently charged with social import. For example, demonstrating that Brazil is very important for Bolivia's rainfall potentially adds a matter for negotiation between the two countries, with all that entails, especially in terms of responsibility and power. Recognition of these implications is critical for natural scientists to become better interdisciplinary scholars as well as responsible and conscientious members of society.

\subsection{Limitations and future work}

Evaporation can be or is actively changed through, e.g., policies, cultural pressures, economic incentives, legal regimes, and treaties in social systems, and it is limited by, e.g., water availability, edaphic suitability, and energy limitation in the biophysical system. The type and nature of this manageable or managed evaporation is important for understanding the management space. Thus, future work could undoubtedly extend and perhaps substantiate social linkages by first identifying and quantifying managed evaporation within different administrative zones. Likewise, specific policies could be linked to these administrative zones, which could explicitly link legal, policy, and on-the-ground management efforts with particular flows of evaporation and subsequently moisture recycling.

The analysis of moisture-recycling relationships, market influence, and child malnutrition suggests a reasonable basis for exploring the social dynamics of moisture recycling more broadly. Existing work has examined the import and export of atmospheric moisture among nations (Dirmeyer et al., 2009), and this work has presented an approach for developing an interdisciplinary understanding of the feedbacks within MRSESs. Future work could explore the social dynamics of the specific countries with the lowest market influence and highest child malnutrition. This type of effort could align well with research agendas targeting the Sustainable Development Goals (SDGs), and specifically with efforts to link moisture recycling to SDG achievement (Keys and Falkenmark, 2018).

\section{Conclusions}

Here, for the first time, we systematically explored the social dynamics of moisture recycling. We provide an approach, based on multiple quantitative and qualitative methods, for revealing the structure of moisture-recycling socialecological systems (MRSESs). We demonstrate this approach using three case studies - Mongolia, Niger, and Bolivia - and describe the social dynamics that have the potential to impact evaporation and subsequently moisture recycling. The key conclusion is that quantitative analysis is not enough to determine which drivers are most important for the social dynamics of moisture-recycling systems. A qualitative understanding, strengthened by a familiarity with rele- vant land-use change drivers, is critical to unraveling whether a region has social dynamics that are isolated, regional, or tele-coupled. Finally, we argue that Earth system scientists ought to explicitly consider the social dynamics of their work to more holistically represent reality as well as to better engage in interdisciplinary science.

Data availability. All data used in this paper are available from other work. The moisture-recycling data for Mongolia, Niger, and Bolivia are available here: https://hdl.handle.net/10217/189237 (last access: 11 June 2018). The market influence data are associated with Verburg et al. (2011) and are available here: http://www.ivm.vu.nl/en/Organisation/departments/ spatial-analysis-decision-support/Market_Influence_Data/index. aspx (last access: 14 November 2014). The malnutrition data are from Socioeconomic and Data Applications Center SEDAC (2005) and are available here: http://sedac.ciesin.columbia.edu/ data/set/povmap-global-subnational-prevalence-child-malnutrition (last access: 22 November 2012). Finally, the anthromes are from Ellis and Ramankutty (2008) and are available here: http://ecotope.org/anthromes/v2/data/ (last access: 15 September 2012).

Author contributions. Both authors contributed to conceptual development, data analysis, and manuscript preparation.

Competing interests. The authors declare that they have no conflict of interest.

Special issue statement. This article is part of the special issue "Social dynamics and planetary boundaries in Earth system modelling". It is not associated with a conference.

Acknowledgements. We appreciate the encouragement of many academic peers to work outside our comfort zone, especially Line Gordon, Thorsten Blenckner, and Sarah Cornell. We also thank the extraordinary and thoughtful comments from four anonymous peer reviewers as well as Paul Dirmeyer and $\mathrm{Mu}-$ rugesu Sivapalan. Their critique and suggestions made this work much more substantial and considered.

Edited by: Murugesu Sivapalan

Reviewed by: Paul Dirmeyer and four anonymous referees

\section{References}

Allan, J. A.: "Virtual water": a long term solution for water short Middle Eastern economies?, School of Oriental and African Studies, University of London, London, 1997.

Badger, A. M. and Dirmeyer, P. A.: Climate response to Amazon forest replacement by heterogeneous crop cover, Hydrol. Earth 
Syst. Sci., 19, 4547-4557, https://doi.org/10.5194/hess-19-45472015, 2015.

Bagley, J. E., Desai, A. R., Dirmeyer, P. A., and Foley, J. A.: Effects of land cover change on moisture availability and potential crop yield in the world's breadbaskets, Environ. Res. Lett., 7, 014009 , https://doi.org/10.1088/1748-9326/7/1/014009, 2012.

Benjaminsen, T. A., Holden, S., Lund, C., and Sjaastad, E.: Formalisation of land rights: Some empirical evidence from Mali, Niger and South Africa, Land Use Policy, 26, 28-35, 2009.

Cosens, B. A. and Williams, M. K.: Resilience and water governance: adaptive governance in the Columbia River basin, Ecol. Soc., 17, 3, https://doi.org/10.5751/ES-04986-170403, 2012.

Damilola, A.: LandUse Act in Nigeria - Explained, available at: https://www.tolet.com.ng/blog/ land-use-act-in-nigeria-explained/ (last access: 28 November 2017), 2017.

De Beurs, K. M. and Henebry, G. M.: Land surface phenology, climatic variation, and institutional change: analyzing agricultural land cover change in Kazakhstan, Remote Sens. Environ., 89, 497-509, 2004.

Dee, D. P., Uppala, S. M., Simmons, A. J., Berrisford, P., Poli, P., Kobayashi, S., Andrae, U., Balmaseda, M. A., Balsamo, G., Bauer, P., Bechtold, P., Beljaars, A. C. M., van de Berg, L., Bidlot, J., Bormann, N., Delsol, C., Dragani, R., Fuentes, M., Geer, A. J., Haimberger, L., Healy, S. B., Hersbach, H., Hólm, E. V., Isaksen, L., Kållberg, P., Köhler, M., Matricardi, M., McNally, A. P., Monge-Sanz, B. M., Morcrette, J. J., Park, B. K., Peubey, C., de Rosnay, P., Tavolato, C., Thépaut, J. N., and Vitart, F.: The ERA-Interim reanalysis: configuration and performance of the data assimilation system, Q. J. Roy. Meteor. Soc., 137, 553-597, https://doi.org/10.1002/qj.828, 2011.

Descheemaeker, K., Amede, T., Haileslassie, A., and Bossio, D.: Analysis of gaps and possible interventions for improving water productivity in crop livestock systems of Ethiopia, Exp. Agr., 47, 21-38, 2011.

Dirmeyer, P. A. and Brubaker, K. L.: Contrasting evaporative moisture sources during the drought of 1988 and the flood of 1993, J. Geophys. Res.-Atmos., 104, 19383-19397, 1999.

Dirmeyer, P. A., Brubaker, K. L., and DelSole, T.: Import and export of atmospheric water vapor between nations, J. Hydrol., 365, 1122, 2009.

Dominguez, F., Kumar, P., Liang, X. Z., and Ting, M.: Impact of atmospheric moisture storage on precipitation recycling, J. Climate, 19, 1513-1530, https://doi.org/10.1175/JCLI3691.1, 2006.

Ellis, E. C. and Ramankutty, N.: Putting people in the map: Anthropogenic biomes of the world, Front. Ecol. Environ., 6, 439-447, 2008.

Ellison, D., Futter, M., and Bishop, K.: On the forest coverwater yield debate: from demand- to supply-side thinking, Glob. Change Biol., 18, 806-820, https://doi.org/10.1111/j.13652486.2011.02589.x, 2012.

Endo, A., Burnett, K., Orencio, P. M., Kumazawa, T., Wada, C. A., Ishii, A., Tsurita, I., and Taniguchi, M.: Methods of the waterenergy-food nexus, Water, 7, 5806-5830, 2015.

Enfors, E.: Social - ecological traps and transformations in dryland agro-ecosystems. Using water system innovations to change the trajectory of development, Global Environ. Chang., 23, 51-60, https://doi.org/10.1016/j.gloenvcha.2012.10.007, 2013.
Finer, M., Jenkins, C. N., Pimm, S. L., Keane, B., and Ross, C.: Oil and gas projects in the western Amazon: threats to wilderness, biodiversity, and indigenous peoples, PloS one, 3, e2932, https://doi.org/10.1371/journal.pone.0002932, 2008.

Flach, R., Ran, Y., Godar, J., Karlberg, L., and Suavet, C.: Towards more spatially explicit assessments of virtual water flows: linking local water use and scarcity to global demand of Brazilian farming commodities, Environ. Res. Lett., 11, 075003, https://doi.org/10.1088/1748-9326/11/7/075003, 2016.

Foley, J. A., Coe, M. T., Scheffer, M., and Wang, G.: Regime Shifts in the Sahara and Sahel: Interactions between Ecological and Climatic Systems in Northern Africa, Ecosystems, 6, 524-532, https://doi.org/10.1007/s10021-002-0227-0, 2003.

Folke, C.: Resilience: The emergence of a perspective for socialecological systems analyses, Global Environ. Chang., 16, 253267, https://doi.org/10.1016/j.gloenvcha.2006.04.002, 2006.

Folke, C., Carpenter, S., Walker, B., Scheffer, M., Elmqvist, T., Gunderson, L., and Holling, C.: Regime Shifts, Resilience, and Biodiversity in Ecosystem Management, Annu. Rev. Ecol. Syst., 35, 557-581, https://doi.org/10.1146/annurev.ecolsys.35.021103.105711, 2004.

Friis, C., Nielsen, J. Ø., Otero, I., Haberl, H., Niewöhner, J., and Hostert, P.: From teleconnection to telecoupling: taking stock of an emerging framework in land system science, Journal of Land Use Science, 11, 131-153, 2016.

Galaz, V., Gars, J., Moberg, F., Nykvist, B., and Repinski, C.: Why ecologists should care about financial markets, Trends Ecol. Evol., 30, 571-580, 2015.

Galaz, V., Tallberg, J., Boin, A., Ituarte-Lima, C., Hey, E., Olsson, P., and Westley, F.: Global Governance Dimensions of Globally Networked Risks: The State of the Art in Social Science Research, Risk, Hazards \& Crisis in Public Policy, 8, 4-27, 2017.

Giordano, M. and Shah, T.: From IWRM back to integrated water resources management, Int. J. Water Resour. D., 30, 364-376, 2014.

Gordon, L. J., Steffen, W., Jönsson, B. F., Folke, C., Falkenmark, M., and Johannessen, A.: Human modification of global water vapor flows from the land surface, P. Natl. Acad. Sci. USA, 102, 7612-7617, https://doi.org/10.1073/pnas.0500208102, 2005.

Gotts, N. M.: Resilience, panarchy, and world-systems analysis, Ecol. Soc., 12, 24, 2007.

Grumbine, R. E., Dore, J., Xu, J.: Mekong hydropower: drivers of change and governance challenges, Front. Ecol. Environ., 10, 91-98, 2012.

Gunderson, L., Cosens, B. A., Chaffin, B. C., Arnold, C. A., Fremier, A. K., Garmestani, A. S., Craig, R. K., Gosnell, H., Birge, H. E., Allen, C. R., and Benson, M. H.: Regime shifts and panarchies in regional scale social-ecological water systems, Ecol. Soc., 22, https://doi.org/10.5751/ES-08879-220131, 2017.

Gunderson, L. H. and Holling, C. S.: Panarchy: understanding transformations in systems of humans and nature, Island press, Washington, USA, 2002.

Halder, S., Saha, S. K., Dirmeyer, P. A., Chase, T. N., and Goswami, B. N.: Investigating the impact of land-use land-cover change on Indian summer monsoon daily rainfall and temperature during 1951-2005 using a regional climate model, Hydrol. Earth Syst. Sci., 20, 1765-1784, https://doi.org/10.5194/hess-20-1765-2016, 2016. 
Hansen, S.: Debt for nature swaps? overview and discussion of key issues, Ecol. Econ., 1, 77-93, 1989.

Heistermann, M.: HESS Opinions: A planetary boundary on freshwater use is misleading, Hydrol. Earth Syst. Sci., 21, 3455-3461, https://doi.org/10.5194/hess-21-3455-2017, 2017.

Hiernaux, P., Ayantunde, A., Kalilou, A., Mougin, E., Gérard, B., Baup, F., Grippa, M., and Djaby, B.: Trends in productivity of crops, fallow and rangelands in Southwest Niger: Impact of land use, management and variable rainfall, J. Hydrol., 375, 65-77, 2009.

Holling, C. S.: Understanding the Complexity of Economic, Ecological, and Social Systems, Ecosystems, 4, 390-405, https://doi.org/10.1007/s10021-001-0101-5, 2001.

Hurrell, A.: The politics of Amazonian deforestation, J. Lat. Am. Stud., 23, 197-215, 1991.

Jargalsaikhan, M.: Mongolia's domestic politics complicate foreign policy in a precarious international setting, Tech. Rep. Asia Pacific Bulletin, No. 399, Washington, DC: East-West Center, available at: https://www.eastwestcenter.org/system/tdf/ private $/$ apb399. pdf?file $=1 \&$ type $=$ node $\& i d=36311$ (last access: 28 November 2017), 2017.

Johansson, E. L., Fader, M., Seaquist, J. W., and Nicholas, K. A.: Green and blue water demand from large-scale land acquisitions in Africa, P. Natl. Acad. Sci. USA, 113, 11471-11476, 2016.

Kainer, K. A., Schmink, M., PINHEIRO LEITE, A. C., and da Silva Fadell, M. J.: Experiments in forest-based development in western Amazonia, Soc. Natural Resour., 16, 869-886, 2003.

Kalamandeen, M., Gloor, E., Mitchard, E., Quincey, D., Ziv, G., Spracklen, D., Spracklen, B., Adami, M., Aragão, L. E., and Galbraith, D.: Pervasive Rise of Small-scale Deforestation in Amazonia, Scientific reports, 8, 1600, https://doi.org/10.1038/s41598-018-19358-2, 2018.

Kendy, E., Molden, D. J., Steenhuis, T. S., Liu, C., and Wang, J.: Policies drain the North China Plain: Agricultural policy and groundwater depletion in Luancheng County, 1949-2000, Vol. 71, IWMI, Colombo, Sri Lanka, 2003.

Keys, P., Barron, J., and Lannerstad, M.: Releasing the pressure: water resource efficiencies and gains for ecosystem services, United Nations Environment Programme, Nairobi, Kenya, 2012.

Keys, P. W. and Falkenmark, M.: Green water and African sustainability, Food Secur., 10, 537-548, https://doi.org/10.1007/s12571-018-0790-7, 2018.

Keys, P. W., Barnes, E. A., van der Ent, R. J., and Gordon, L. J.: Variability of moisture recycling using a precipitationshed framework, Hydrol. Earth Syst. Sci., 18, 3937-3950, https://doi.org/10.5194/hess-18-3937-2014, 2014.

Keys, P. W., Wang-Erlandsson, L., and Gordon, L. J.: Revealing invisible water: moisture recycling as an ecosystem service, PloS one, 11, e0151993, https://doi.org/10.1371/journal.pone.0151993, 2016.

Keys, P. W., Wang-Erlandsson, L., Gordon, L. J., Galaz, V., and Ebbesson, J.: Approaching moisture recycling governance, Global Environ. Chang., 45, 15-23, 2017.

Keys, P. W., Wang-Erlandsson, L., and Gordon, L. J.: Megacity precipitationsheds reveal tele-connected water security challenges, PloS one, https://doi.org/10.1371/journal.pone.0194311, 2018.

Killeen, T. J., Calderon, V., Soria, L., Quezada, B., Steininger, M. K., Harper, G., Solórzano, L. A., and Tucker, C. J.: Thirty years of land-cover change in Bolivia, AMBIO, 36, 600-606, 2007.

Killeen, T. J., Guerra, A., Calzada, M., Correa, L., Calderon, V., Soria, L., Quezada, B., and Steininger, M.: Total historical land-use change in eastern Bolivia: Who, where, when, and how much?, Ecol. Soc., 13, 36, 2008.

Koster, R., Jouzel, J., Suozzo, R., Russell, G., Broecker, W., Rind, D., and Eagleson, P.: Global sources of local precipitation as determined by the NASA/GISS GCM, Geophys. Res. Lett., 13, 121-124, 1986.

Land Matrix Global Observatory: available at: http: //www.landmatrix.org/en/get-the-detail/by-target-country/ nigeria/?order_by=\&starts_with=N (last access: 15 May 2018), 2018.

Lawrence, D. and Vandecar, K.: Effects of tropical deforestation on climate and agriculture, Nat. Clim. Change, 5, 27-36, 2015.

Lettau, H., Lettau, K., and Molion, L. C.: Amozonia's hydrological cycle and the role of atmospheric recycling in assessing deforestation effects, Mon. Weather Rev., 107, 227-238, 1979.

Levin, S., Xepapadeas, T., Crépin, A.-S., Norberg, J., De Zeeuw, A., Folke, C., Hughes, T., Arrow, K., Barrett, S., Daily, G., et al.: Social-ecological systems as complex adaptive systems: modeling and policy implications, Environ. Dev. Econ., 18, 111-132, 2013.

Liu, J., Mooney, H., Hull, V., Davis, S. J., Gaskell, J., Hertel, T., Lubchenco, J., Seto, K. C., Gleick, P., Kremen, C., and Li, S.: Systems integration for global sustainability, Science, 347, 1258832, https://doi.org/10.1126/science.1258832, 2015.

Lo, M. and Famiglietti, J. S.: Irrigation in California's Central Valley strengthens the southwestern U.S. water cycle, Geophys. Res. Lett., 40, 301-306, https://doi.org/10.1002/grl.50108, 2013.

Malhi, Y., Adu-Bredu, S., Asare, R. A., Lewis, S. L., and Mayaux, P.: African rainforests: past, present and future, Philos. T. R. Soc. B, 368, 20120312, https://doi.org/10.1098/rstb.2012.0312, 2013.

Meyfroidt, P., Schierhorn, F., Prishchepov, A. V., Müller, D., and Kuemmerle, T.: Drivers, constraints and trade-offs associated with recultivating abandoned cropland in Russia, Ukraine and Kazakhstan, Global Environmen. Chang., 37, 1-15, 2016.

Mortimore, M. J. and Tiffen, M.: Population Growth and a Sustainable Environment, Environment, 36, 16, 1994.

Nasi, R., Billand, A., and van Vliet, N.: Managing for timber and biodiversity in the Congo Basin, Forest Ecol. Manag., 268, 103$111,2012$.

Neal, M. J., Lukasiewicz, A., and Syme, G. J.: Why justice matters in water governance: some ideas for a "water justice framework", Water Policy, 16, 1-18, 2012.

Ojima, D. and Chuluun, T.: Policy changes in Mongolia: implications for land use and landscapes, Fragmentation in semi-arid and arid landscapes, in: Fragmentation in Semi-Arid and Arid Landscapes: Consequences for Human and Natural Systems, 179193, Springer, the Netherlands, 2008.

Osabuohien, E. S.: Large-scale agricultural land investments and local institutions in Africa: The Nigerian case, Land Use Policy, 39, 155-165, 2014.

Ostrom, E.: A general framework for analyzing sustainability of social-ecological systems, Science, 325, 419-422, https://doi.org/10.1126/science.1172133, 2009.

Perz, S. G., Aramburú, C., and Bremner, J.: Population, land use and deforestation in the Pan Amazon Basin: a comparison of Brazil, 
Bolivia, Colombia, Ecuador, Perú and Venezuela, Environ. Dev. Sustain., 7, 23-49, 2005.

Priess, J. A., Schweitzer, C., Wimmer, F., Batkhishig, O., and Mimler, M.: The consequences of land-use change and water demands in Central Mongolia, Land Use Policy, 28, 4-10, 2011.

Robinson, S., Milner-Gulland, E., and Alimaev, I.: Rangeland degradation in Kazakhstan during the Soviet era: re-examining the evidence, J. Arid Environ., 53, 419-439, 2003.

Rockström, J., Barron, J., and Fox, P.: Rainwater management for increased productivity among small-holder farmers in drought prone environments, Phys. Chem. Earth, 27, 949-959, 2002.

Rockström, J., Falkenmark, M., Karlberg, L., Hoff, H., Rost, S., and Gerten, D.: Future water availability for global food production: The potential of green water for increasing resilience to global change, Water Resour. Res., 45, W00A12, https://doi.org/10.1029/2007WR006767, 2009.

Rockström, J., Falkenmark, M., Lannerstad, M., and Karlberg, L.: The planetary water drama: Dual task of feeding humanity and curbing climate change, Geophys. Res. Lett., 39, L15401, https://doi.org/10.1029/2012GL051688, 2012.

Roncoli, C., Ingram, K., and Kirshen, P.: Reading the rains: local knowledge and rainfall forecasting in Burkina Faso, Soc. Natur. Resour., 15, 409-427, 2002.

Salih, A. A. M., Körnich, H., and Tjernström, M.: Climate impact of deforestation over South Sudan in a regional climate model, Int. J. Climatol., 33, 2362-2375, https://doi.org/10.1002/joc.3586, 2013.

Saruchera, D. and Lautze, J.: Measuring transboundary water cooperation: learning from the past to inform the sustainable development goals, Vol. 168, International Water Management Institute (IWMI), Colombo, Sri Lanka, 2015.

Savenije, H. H. G.: New definitions for moisture recycling and the relationship with land-use changes in the Sahel, J. Hydrol., 167, 57-78, 1995.

Simoes, A. and Hidalgo, C.: The Economic Complexity Observatory: An Analytical Tool for Understanding the Dynamics of Economic Development, available at: https://atlas.media.mit. edu/en/ (last access: 28 November 2017), 2011.

Sivapalan, M., Savenije, H. H., and Blöschl, G.: Socio-hydrology: A new science of people and water, Hydrol. Process., 26, 12701276, 2012.

Socioeconomic and Data Applications Center SEDAC: Poverty Mapping Project: Global Subnational Prevalence of Child Malnutrition, data retrieved from Socioeconomic Data and Applications Center (SEDAC), https://doi.org/10.7927/H4K64G12, 2005.

Spracklen, D. and Garcia-Carreras, L.: The impact of Amazonian deforestation on Amazon basin rainfall, Geophys. Res. Lett., 42, 9546-9552, https://doi.org/10.1002/2015GL066063, 2015.

Steffen, W., Richardson, K., Rockström, J., Cornell, S. E., Fetzer, I., Bennett, E. M., Biggs, R., Carpenter, S. R., De Vries, W., de Wit, C. A., and Folke, C.: Planetary boundaries: Guiding human development on a changing planet, Science, 347, 1259855, https://doi.org/10.1126/science.1259855, 2015.

Swann, A. L., Longo, M., Knox, R. G., Lee, E., and Moorcroft, P. R.: Future deforestation in the Amazon and consequences for South American climate, Agr. Forest Meteorol., 214, 12-24, https://doi.org/10.1016/j.agrformet.2015.07.006, 2015.
Thompson, S. E., Sivapalan, M., Harman, C. J., Srinivasan, V., Hipsey, M. R., Reed, P., Montanari, A., and Blöschl, G.: Developing predictive insight into changing water systems: useinspired hydrologic science for the Anthropocene, Hydrol. Earth Syst. Sci., 17, 5013-5039, https://doi.org/10.5194/hess-17-50132013, 2013.

Toulmin, C.: Securing land and property rights in sub-Saharan Africa: the role of local institutions, Land Use Policy, 26, 1019, 2009.

Tschakert, P.: Views from the vulnerable: Understanding climatic and other stressors in the Sahel, Global Environ. Chang., 17, 381-396, https://doi.org/10.1016/j.gloenvcha.2006.11.008, 2007.

Tuinenburg, O. A., Hutjes, R. W. A., Stacke, T., Wiltshire, A., and Lucas-Picher, P.: Effects of Irrigation in India on the Atmospheric Water Budget, J. Hydrometeorol., 15, 1028-1050, https://doi.org/10.1175/JHM-D-13-078.1, 2014.

USAID: Country Profile: Chad, available at: https://www. land-links.org/country-profile/chad/ (last access: 6 October 2017), 2010.

USAID: Country Profile: Sudan, available at: https://www. land-links.org/country-profile/sudan/ (last access: 6 October 2017), 2013.

van der Ent, R. J., Savenije, H. H., Schaefli, B., and Steele-Dunne, S. C.: Origin and fate of atmospheric moisture over continents, Water Resour. Res., 46, W09525, https://doi.org/10.1029/2010WR009127, 2010.

van der Ent, R. J., Tuinenburg, O. A., Knoche, H.-R., Kunstmann, H., and Savenije, H. H. G.: Should we use a simple or complex model for moisture recycling and atmospheric moisture tracking?, Hydrol. Earth Syst. Sci., 17, 4869-4884, https://doi.org/10.5194/hess-17-4869-2013, 2013.

Verburg, P. H., Ellis, E. C., and Letourneau, A.: A global assessment of market accessibility and market influence for global environmental change studies, Environ. Res. Lett., 6, 034019, https://doi.org/10.1088/1748-9326/6/3/034019, 2011.

Verweij, P., Schouten, M., Van Beukering, P., Triana, J., Van der Leeuw, K., and Hess, S.: Keeping the Amazon forests standing: a matter of values, WWF-Netherlands, Zeist, 2009.

Vrese, P., Hagemann, S., and Claussen, M.: Asian irrigation, African rain: Remote impacts of irrigation, Geophys. Res. Lett., 43, 3737-3745, https://doi.org/10.1002/2016GL068146, 2016.

Wada, Y., Bierkens, M. F. P., de Roo, A., Dirmeyer, P. A., Famiglietti, J. S., Hanasaki, N., Konar, M., Liu, J., Müller Schmied, H., Oki, T., Pokhrel, Y., Sivapalan, M., Troy, T. J., van Dijk, A. I. J. M., van Emmerik, T., Van Huijgevoort, M. H. J., Van Lanen, H. A. J., Vörösmarty, C. J., Wanders, N., and Wheater, H.: Human-water interface in hydrological modelling: current status and future directions, Hydrol. Earth Syst. Sci., 21, 4169-4193, https://doi.org/10.5194/hess-21-4169-2017, 2017.

Walther, B. A.: A review of recent ecological changes in the Sahel, with particular reference to land-use change, plants, birds and mammals, Afr. J. Ecol., 54, 268-280, 2016.

Wang-Erlandsson, L., Bastiaanssen, W. G. M., Gao, H., Jägermeyr, J., Senay, G. B., van Dijk, A. I. J. M., Guerschman, J. P., Keys, P. W., Gordon, L. J., and Savenije, H. H. G.: Global root zone storage capacity from satellite-based evaporation, Hydrol. Earth Syst. Sci., 20, 1459-1481, https://doi.org/10.5194/hess-20-14592016, 2016. 
Wei, J., Dirmeyer, P. A., Wisser, D., Bosilovich, M. G., and Mocko, D. M.: Where Does the Irrigation Water Go? An Estimate of the Contribution of Irrigation to Precipitation Using MERRA, J. Hydrometeorol., 14, 275-289, https://doi.org/10.1175/JHM-D-12079.1, 2013.

Zalasiewicz, J., Waters, C. N., Williams, M., Barnosky, A. D., Cearreta, A., Crutzen, P., Ellis, E., Ellis, M. A., Fairchild, I. J., Grinevald, J., and Haff, P. K.: When did the Anthropocene begin? A mid-twentieth century boundary level is stratigraphically optimal, Quaternary Int., 383, 196-203, 2015.
Zhou, T., Nijssen, B., Gao, H., and Lettenmaier, D. P.: The contribution of reservoirs to global land surface water storage variations, J. Hydrometeorol., 17, 309-325, 2016. 